\title{
An investigation of very low calorie intakes reported in Jamaica
}

\author{
BY ANN ASHWORTH \\ Medical Research Council, Tropical Metabolism Research Unit, \\ University of the West Indies, Famaica
}

(Received 28 fuly I967-Accepted 5 February 1968)

\begin{abstract}
I. A previous dietary survey has reported some very low calorie intakes in a farming community in rural Jamaica. Subsequently, ten subjects were specially selected on the basis of being very poor and underfed and individual dietary surveys were carried out in their homes for 7 days.

2. The accuracy of the dietary surveys was tested in a metabolic ward by feeding the subjects with the same meals as were recorded in their homes. Body-weight, calorie and nitrogen intakes, and urinary and faecal $\mathrm{N}$ outputs were measured.

3. Basal metabolic rates and the calorie expenditure during sleep were measured to investigate whether any metabolic adaptations to the low calorie intakes had occurred. The calorie cost of performing a standard step-test was measured and compared with that of well-fed control subjects to find out if there were differences in physical efficiency.

4. Nine of the subjects were found to be thinner than the average person of the same age and sex in their district, and were considerably thinner than the average American.

5. Five of the dietary surveys were thought to have given a correct picture of the normal dietary pattern. The remaining five surveys were unsatisfactory.

6. In the five correct surveys, calorie intakes were $61,69,72,78$ and $98 \%$ of the FAO recommended requirements.

7. No clear-cut evidence of an adaptive change in basal metabolic rate was found.

8. Few calorics were available for physical exertion and there was an apparent increase in the physical efficiency of work.
\end{abstract}

A detailed dietary survey carried out in Jamaica during 1959-6o by E. K. Cruickshank \& H. Fox (unpublished) revealed some remarkably low calorie intakes among people living in a rural community called Lawrence Tavern. A number of nutrition surveys in various parts of the world have also shown similar low calorie intakes.

In the survey of Lawrence Tavern sixty families selected at random were studied and every item of food consumed by each person in the household during I week was weighed by trained field workers. The field workers also recorded occupation and graded it as heavy, moderate or light. The work of the majority of men was classed as heavy. Since the amenities were few, water and other household necessities often had to be carried considerable distances by the women. Calorie intakes recorded as low as $1000-1500 \mathrm{kcal} /$ day were therefore surprising, and posed the question of how people manage to work on such low intakes without apparently any excessive loss in bodyweight.

Possible explanations are:

(a) that the results of the dietary surveys were wrong;

(b) that some kind of adaptation to the low calorie intakes had occurred such as (1) a lowering in basal metabolic rate (BMR), (2) a large fall in metabolism during sleep, (3) an improvement in physical efficiency; 
(c) that the level of physical activity had been overestimated.

The aim of the work described in this paper was to investigate the first two possibilities. We were not able to make a full time-and-motion study in the field which would be necessary to test the third possibility, but an attempt was made to keep a diary of the day's activities.

\section{EXPERIMENTAL}

\section{Selection of subjects}

The subjects were selected by a field worker attached to the Medical Research Council's Epidemiological Unit, who has been working full time in the Lawrence Tavern district for over 2 years. She was asked to find ten male volunteers who, in her experience, always had been very poor and always had little to eat. It proved difficult to persuade the men to volunteer as they were reluctant to leave their cultivations, but their women-folk were willing and the project was revised so that the subjects comprised five males and five females. Eventually, three of the men had to be recruited from a different area, Penfield. The control subjects were five male West Indian medical students of the University, and five female Jamaican staff of the Tropical Metabolism and Epidemiological Research Units.

\section{Environment}

The Lawrence Tavern and Penfield districts are situated 12 miles and 7 miles respectively from Kingston. Both districts are very hilly and lie about 1000-1500 ft above sea level. The mean annual maximum temperature is $83^{\circ} \mathrm{F}$, with a small seasonal variation ranging from a mean of $8 \mathrm{r}{ }^{\circ} \mathrm{F}$ during January to $86^{\circ} \mathrm{F}$ in July. Relative humidity is very constant with an annual mean of $85 \%$. Lawrence Tavern is a predominantly farming community and the majority of households are self-supporting in such commodities as yams, potato, sweet potato, cassava, breadfruit, maize, ackee (Blighia sapida), callaloo (Amaranthus viridis), cho-cho (Sechium edule), coconut oil and various fruits. The main items purchased include bread, rice, flour, sugar, maize meal, condensed milk, saltfish and beef. The women spend a considerable portion of the day plaiting straw for making into hats and bags.

Penfield is a much less fertile district and few crops are grown there. However, most families have plots of land elsewhere and cultivate yams, cassava, congo peas (Cajanus indicus) and red peas (Phaseolus vulgaris), bananas, sweet potato, breadfruit and chocho. The chief items purchased are similar to those of Lawrence Tavern and the diets in both districts are high in carbohydrate and low in fat and protein. The men of Penfield take on casual manual labour such as road repairs. None of the houses in either district has water or electricity supplies. More detailed descriptions of each individual's home environment and activities can be found in the Appendix.

\section{Nutritional survey techniques}

The dietary intakes of the selected subjects were measured in their homes for 7 consecutive days, following closely the technique used by Cruickshank \& Fox in the previous survey of Lawrence Tavern. In addition, after the evening meal was over the 
scales were left in the home so that it was possible for any additional item of food or drink, consumed in the author's absence, to be weighed. Although the ingredients of composite dishes were weighed during preparation whenever possible, some items were purchased ready cooked from the village shop. Occasionally food was consumed away from the home, in which event as detailed a record as possible was made.

At the end of each field study, the subject was brought into the metabolic ward for a further 7 days and given the same food, both in type and amount, as was recorded in the home. Body-weight was measured each morning, before breakfast and after the subject had urinated, on a beam balance sensitive to $5 \mathrm{~g}$.

A duplicate of each meal eaten in the ward was put into a polythene bag, one bag being used per day. Each day's food was then deep-frozen, and later freeze-dried and made into a fine powder by passing it through a hammer mill. The calorie value was measured with a ballistic bomb calorimeter and the nitrogen content by the microKjeldahl method so that the daily calorie and nitrogen intakes were accurately known. Because of losses in the urine and faeces, the metabolizable energy provided by the food would be less than the measured calorie intake; this difference was calculated to be between 5 and $7 \%$, on the basis that unoxidized material in the urine represented $7.9 \mathrm{kcal} / \mathrm{g} \mathrm{N}$ (Atwater \& Bryant, 1900), and that protein was $92 \%$, fat $95 \%$ and carbohydrate $97 \%$ absorbed (Atwater, I902).

\section{Metabolic measurements}

Measurement of metabolism during sleep. In order to obtain the basal metabolic rate and to find out whether there was a large fall in metabolism during sleep, metabolic rates were measured continuously from 22.00 to $06.00 \mathrm{~h}$ during each night in the ward. The method employed was a modification of that used by Furnass (1959), but avoided the need for an integrating motor pneumotachograph (Wolff, 1958).

The apparatus consisted of a ventilated hood connected to a vacuum cleaner. The subject slept with his head on a pillow inside the hood and a stream of fresh air was sucked over his face. Diluted expired air left the hood through an outlet in the rear wall and its volume was measured with a gas meter. A narrow side-arm fitted to the outlet immediately proximal to the hood enabled continuous samples of diluted expired air to be diverted by an aquarium pump into a 11 . sampling bag.

The total volume of diluted expired air diverted to the sampling bag was disregarded, as it was negligible compared with the total volume passing through the gas meter. Diffusion of $\mathrm{CO}_{2}$ outwards from the sampling bag was minimized by placing it inside a box through which the effluent from the vacuum cleaner was passed. Safety circuits were incorporated into the hood so that if for any reason the air flow through the hood stopped, an emergency blower mounted in the rear wall of the hood came into operation and blew air into the hood.

The subject entered the hood at $20.00 \mathrm{~h}$ and was usually asleep when collections began at $22.00 \mathrm{~h}$. There were four collecting periods, each lasting $2 \mathrm{~h}$ and finally ending at $06.00 \mathrm{~h}$. The samples of diluted expired air were then analysed for $\mathrm{CO}_{2}$ with a Lloyd gas analyser and for $\mathrm{O}_{2}$ with a portable oxygen analyser (Servomex). The RQ and metabolic rates during the $2 \mathrm{~h}$ periods were calculated. 
Of the four collection periods, the one which was closest to the standard definition for the measurement of BMR was the 04.00 to $06.00 \mathrm{~h}$ period because of the longer interval after the last meal, and therefore the metabolic rate measured during this period was taken as the BMR. The formula of Du Bois \& Du Bois (19i6) was used to calculate the BMR $/ \mathrm{m}^{2}$ :

$$
\text { Surface in } \mathrm{m}^{2}=0.007184 \times \text { weight in } \mathrm{kg}^{0.425} \times \text { height in } \mathrm{cm}^{0.725} \text {. }
$$

The values for the BMR were compared with the Fleisch standards (Fleisch, I95I). These standard values were corrected for climatic conditions by a deduction of $10 \%$ as recommended in the FAO report on calorie requirements (FAO: Second Committee on Calorie Requirements, 1957).

In order to determine whether there was any large fall in metabolism during sleep the minimal metabolic rate observed each night was compared with the rate between 04.00 and $06.00 \mathrm{~h}$.

Measurement of physical efficiency. (I) Step-testing: in order to evaluate whether physical efficiency was increased in the test subjects compared with the controls, a standardized step-test was performed on a 9 in. step at a rate of $20 \mathrm{steps} / \mathrm{min}$ for Io min. The subject, using a mouthpiece suspended above the step and wearing a nose clip, breathed out through the expiratory valve along flexible tubing into a gas meter with which the volume of expired air was measured. At the inlet to the gas meter a side-arm was fixed to enable a representative fraction of expired air to be diverted into a sample bag at a rate of $100 \mathrm{ml} / \mathrm{min}$ by means of an aquarium pump. The sample of expired air was then analysed for $\mathrm{CO}_{2}$ and $\mathrm{O}_{2}$, and the RQ and calorie expenditure were calculated. The test was performed twice each day in the midmorning, with a $\mathrm{I} h$ interval between tests. The number of heart beats for the first 3 min of recovery was also measured as part of the step-test.

(2) Brick carrying: each day the test subjects were required to move Ioo bricks a distance of $30 \mathrm{yd}$, to stack them and then to move them back. They were told they could move them in whatever manner they wished and could rest when they liked so long as the task was completed within $2 \mathrm{~h}$. The manner in which the bricks were moved and stacked and the time taken were noted. The purpose of the brick carrying was to prevent the subjects from being completely sedentary and to obtain more information on the efficiency with which the subjects planned and carried out a physical task. Therefore on the final day each subject was asked to move the bricks in his usual way and the calorie cost of doing this was determined by the Douglas bag technique. The operation was then repeated with the subject carrying more bricks, then fewer bricks at a time and the calorie cost of each determined. The calorie cost of sitting was also measured for each subject at this stage.

It is impossible to say with any accuracy how the subjects' activity in the ward compared with their activity at home. The impression from the work diaries was that the girls spent a vast amount of their time at home plaiting straw-an occupation which they continued during their stay in the ward. The male subjects seemed more active at home than in the ward. 


\section{RESULTS}

Body size

The heights and weights of the subjects and controls together with their ages are shown in Table I. The male test subjects were considerably shorter and lighter than the controls. The female test subjects were similar in height to the controls but again were lighter.

The weight:height ratio was used as an index of 'thinness' and was calculated by dividing the weight in $\mathrm{g}$ by the height in $\mathrm{cm}$. A thin person would therefore have a lower ratio than a heavier person of the same height. The subjects' weight:height ratios were compared with the mean weight:height ratios for Lawrence Tavern persons of the same age and sex (Table I), the figures for which were obtained from the original data of an anthropometric survey (Ashcroft, Ling, Lovell \& Miall, I966). The results indicate that the test subjects with the exception of V.P. were thinner than the average Lawrence Tavern person of the same age and sex, and were thinner than the controls.

Table I. Heights, weights and weight:height ratios of the test subjects and controls, and the mean weight: height ratios for Lawrence Tavern persons of the same age and sex

\begin{tabular}{|c|c|c|c|c|c|}
\hline Subject & $\begin{array}{c}\text { Age } \\
\text { (years) }\end{array}$ & $\begin{array}{c}\text { Height } \\
\text { (cm) }\end{array}$ & $\begin{array}{c}\text { Weight } \\
\text { (kg) }\end{array}$ & $\begin{array}{l}\text { Weight: height } \\
\text { ratio }\end{array}$ & $\begin{array}{c}\text { Mean } \\
\text { Lawrence Tavern } \\
\text { weight: height } \\
\text { ratio }\end{array}$ \\
\hline \multicolumn{6}{|c|}{ Male test subjects } \\
\hline J.B. & 32 & 168 & $57^{\cdot 2}$ & $34^{\circ}$ & 367 \\
\hline R.F. & $x$ & 167 & $56 \cdot 8$ & 340 & 347 \\
\hline L.R. & 17 & 162 & $49 \cdot 4$ & 305 & 319 \\
\hline T.D. & 18 & 175 & $54 \cdot 6$ & 312 & 347 \\
\hline D.M. & I 8 & 164 & $56 \cdot 0$ & $34 \mathrm{I}$ & 347 \\
\hline Mean & 20 & 167 & $54 \cdot 8$ & 328 & 346 \\
\hline \multicolumn{6}{|c|}{ Male control subjects } \\
\hline F.B. & 20 & I9I & $79 \cdot 6$ & 417 & - \\
\hline N.M. & 22 & x 80 & $72 \cdot 6$ & 403 & - \\
\hline D.W. & 20 & 183 & $78 \cdot 7$ & $43^{\circ}$ & - \\
\hline L.C. & 26 & 174 & $66 \cdot 6$ & 383 & - \\
\hline C.C. & 23 & 162 & $64 \cdot 5$ & 398 & - \\
\hline Mean & 22 & 178 & $72 \cdot 4$ & 406 & - \\
\hline \multicolumn{6}{|c|}{ Female test subjects } \\
\hline H.C. & 20 & 163 & $48 \cdot 1$ & 295 & $33^{8}$ \\
\hline E.L. & 20 & 150 & $45^{\cdot 8}$ & 305 & $33^{8}$ \\
\hline R.L. & I6 & 153 & $44 \cdot 3$ & 289 & 324 \\
\hline M.D. & $2 I$ & 164 & $42 \cdot 0$ & 256 & $33^{8}$ \\
\hline V.P. & I7 & $16 r$ & $54^{\circ} 0$ & 335 & 333 \\
\hline Mean & I9 & 158 & $46 \cdot 8$ & 296 & 334 \\
\hline \multicolumn{6}{|c|}{ Female control subjects } \\
\hline G.B. & 23 & 165 & $65^{\circ} \circ$ & 394 & 一 \\
\hline P.M. & I 8 & 156 & $55 \cdot 1$ & 353 & - \\
\hline J.I. & I9 & 152 & $47^{\circ} \circ$ & 309 & - \\
\hline S.C. & 22 & 154 & $48 \cdot 9$ & 317 & - \\
\hline J.G. & 22 & I 54 & $47^{\prime} I$ & 306 & - \\
\hline Mean & $2 I$ & $\times 56$ & $52 \cdot 6$ & 336 & - \\
\hline
\end{tabular}




\section{Dietary intakes}

Calorie intakes. The mean daily calorie intakes of the individual subjects are given in Table 2. In addition, the intakes have been expressed as a percentage of the reference calorie requirements for persons of the same age, sex, body-weight and climatic environment, as recommended in the report of the FAO: Second Committee on Calorie Requirements (1957).

Table 2. Daily calorie intakes and nitrogen balances, ${ }^{*}$ and the overall change in body-weight during the period spent in the ward

\begin{tabular}{|c|c|c|c|c|c|c|c|c|}
\hline \multirow[b]{2}{*}{ Sex } & \multirow[b]{2}{*}{ Subject } & \multirow[b]{2}{*}{$\begin{array}{c}\text { Calorie } \\
\text { intake } \\
\text { (kcal/day) }\end{array}$} & \multirow{2}{*}{$\begin{array}{c}\text { Intake as } \\
\% \text { FAO } \\
\text { calorie } \\
\text { require- } \\
\text { ments } \\
(\%)\end{array}$} & \multirow[b]{2}{*}{$\begin{array}{c}N \text { intake } \\
(\mathrm{g} / \text { day })\end{array}$} & \multicolumn{2}{|c|}{$\mathrm{N}$ output } & \multirow[b]{2}{*}{$\begin{array}{l}\text { Balance } \\
\text { (g/day) }\end{array}$} & \multirow{2}{*}{$\begin{array}{c}\text { Over-all } \\
\text { change } \\
\text { in weight } \\
(\mathrm{kg})\end{array}$} \\
\hline & & & & & $\begin{array}{l}\text { Urine } \\
\text { (g/day) }\end{array}$ & $\begin{array}{l}\text { Faeces } \\
\text { (g/day) }\end{array}$ & & \\
\hline Male & $\begin{array}{l}\text { J.B. } \\
\text { R.F. } \\
\text { L.R. } \\
\text { T.D. } \\
\text { D.M. }\end{array}$ & $\begin{array}{l}1106 \\
1596 \\
2226 \\
2074 \\
1641\end{array}$ & $\begin{array}{l}43 \\
52 \\
78 \\
72 \\
57\end{array}$ & $\begin{array}{l}2 \cdot 27 \\
6 \cdot 31 \\
9 \cdot 46 \\
9 \cdot 37 \\
8 \cdot 34\end{array}$ & $\begin{array}{l}3.24 \\
5.85 \\
6.38 \\
6.11 \\
7.83\end{array}$ & $\begin{array}{l}0.26 \\
1 \cdot 21 \\
I \cdot 01 \\
0.48 \\
-\end{array}$ & $\begin{array}{l}-1.23 \\
-0.75 \\
+2.07 \\
+2.78 \\
-0.32 \dagger\end{array}$ & $\begin{array}{l}-2.39 \\
-0.66 \\
+0.10 \\
-0.32 \\
-0.76\end{array}$ \\
\hline Female & $\begin{array}{l}\text { H.C. } \\
\text { E.L. } \\
\text { R.L. } \\
\text { M.D. } \\
\text { V.P. }\end{array}$ & $\begin{array}{l}1232 \\
1821 \\
1356 \\
1185 \\
1607\end{array}$ & $\begin{array}{l}61 \\
98 \\
73 \\
69 \\
74\end{array}$ & $\begin{array}{l}4.43 \\
8.75 \\
6.11 \\
5.83 \\
5.02\end{array}$ & $\begin{array}{l}4 \cdot 48 \\
5 \cdot 79 \\
4 \cdot 64 \\
4 \cdot 42 \\
8 \cdot 08\end{array}$ & $\begin{array}{l}0.32 \\
1 \cdot 46 \\
0.59 \\
0.35 \\
1.80\end{array}$ & $\begin{array}{l}-0.37 \\
+1.50 \\
+0.88 \\
+1.06 \\
-4.86\end{array}$ & $\begin{array}{l}-0.16 \\
-0.02 \\
-0.78 \\
+0.12 \\
-1.12\end{array}$ \\
\hline
\end{tabular}

* Mean values for 7 days except J.B. 5 days only.

$\uparrow$ Subject D.M. did not produce a stool and therefore his $\mathrm{N}$ balance was calculated from the mean faecal loss of the other subjects $(0.83 \mathrm{~g} \mathrm{~N})$.

The difference in body-weight between the first and last days of the period spent in the ward is shown in Table 2. It is always difficult to conclude from changes in bodyweight whether or not a subject is in calorie balance because of possible variations in body water. For example, Durnin (196I) and Edholm (196r) have shown that weight changes of up to $\mathrm{I} \mathrm{kg}$ can be simply a normal daily fluctuation. It is also doubtful whether an analysis of regression on the day-to-day weight changes is useful for a 7 -day period in differentiating between a normal fluctuation and a small but continuous weight loss. However, the results suggest that subjects J.B. and V.P. were not in calorie balance and that their normal calorie intake had been underestimated, either because the survey week was atypical or because the survey did not record everything that was consumed. No definite conclusion can be drawn about the other subjects, but it may be significant that all but two lost some weight.

Nitrogen intakes. The mean daily $\mathrm{N}$ intakes are shown in Table 2 together with the mean daily urinary and faecal $\mathrm{N}$ losses. Since no allowance was made for $\mathrm{N}$ losses from the skin, the negative balances were probably real, and indicate that the protein intakes must have been underestimated in the field survey (see p. 35I). On the whole the findings agree with those for calorie intake and weight loss: the five subjects who were in negative $\mathrm{N}$ balance all lost weight and in four of these the weight losses were greater than $0.5 \mathrm{~kg}$. 


\section{Metabolism during sleep}

Fig. I illustrates the individual patterns of metabolism during sleep. Metabolic rates are shown for the four 2-hourly periods from 22.00 to $06.00 \mathrm{~h}$ and are the mean of measurements made daily for 7 days. Five of the subjects had metabolic rates which were lowest on average between 04.00 and $06.00 \mathrm{~h}$, three were lowest between 02.00 and $04.00 \mathrm{~h}$, one was lowest during the 24.00 to $02.00 \mathrm{~h}$ period and one was lowest between 22.00 and $24.00 \mathrm{~h}$.

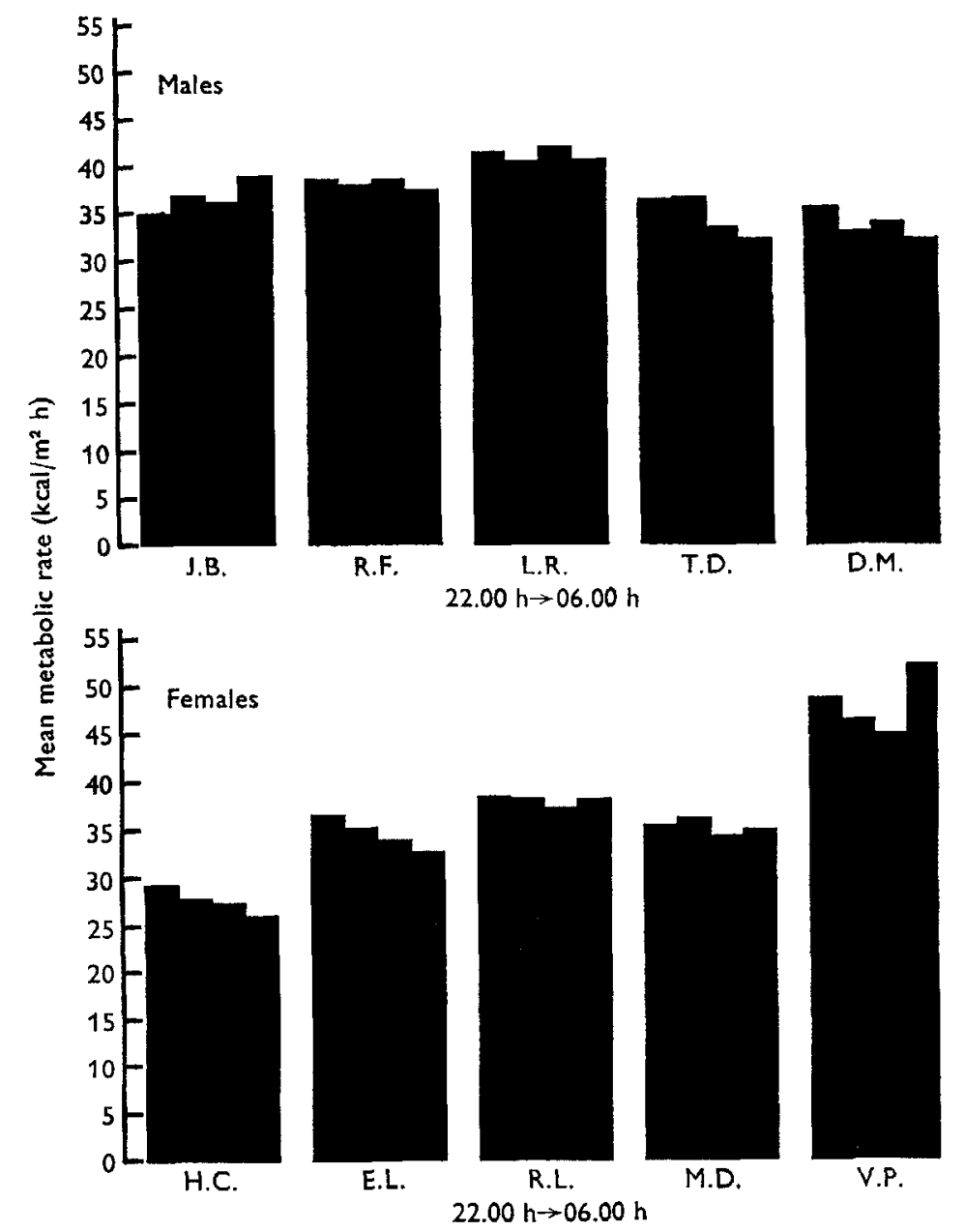

Fig. I. Pattern of metabolism of Jamaican subjects during sleep from 22.00 to $06.00 \mathrm{~h}$ measured in four 2-hourly periods.

In order to obtain the minimal metabolic rate, the lowest metabolic rate recorded each night was taken and the mean calculated. These minimal rates and the 04.00$06.00 \mathrm{~h}$ metabolic rates are shown for comparison in Table 3, together with the standard BMR, corrected for temperature (Fleisch, 195I), for subjects of the same age and sex. 
Table 3 shows that minimal metabolism did not always occur between 04.00 and $06.00 \mathrm{~h}$. Two subjects, J.B. and V.P., tended to become restless at about $05.00 \mathrm{~h}$, which accounts for their $04.00-06.00 \mathrm{~h}$ metabolic rate being considerably higher than their minimal rate.

In three of the subjects (T.D., D.M. and H.C.) the minimal metabolic rate was about $5 \%$ lower than the expected BMr. In one, V.P., it was much higher and in the others the minimal rate was close to the expected BMR.

All the subjects had normal RQs and the mean $04.00-06.00 \mathrm{~h}$ values ranged from 0.8 I to 0.9 I. Subjects J.B. and V.P., who showed the greatest weight losses, had RQs of 0.86 and 0.82 respectively.

Table 3. A comparison of the minimal metabolic rate, the 04.00-06.00 h metabolic rate, the standard BMR and the calorie cost of sitting $\left(\mathrm{kcal} / \mathrm{m}^{2} \mathrm{per} h\right)$

\begin{tabular}{|c|c|c|c|c|c|}
\hline Sex & Subject & $\begin{array}{l}\text { Minimal } \\
\text { metabolic rate* }\end{array}$ & $\begin{array}{l}04.00-06.00 \mathrm{~h} \\
\text { metabolic rate* }\end{array}$ & $\begin{array}{c}\text { Standard } \\
\text { BMR } \\
\text { (- 10\% for } \\
\text { climate) }\end{array}$ & $\begin{array}{l}\text { Calorie } \\
\text { cost of sitting } \\
\text { (one measure- } \\
\text { ment only) }\end{array}$ \\
\hline Male & $\begin{array}{l}\text { J.B. } \\
\text { R.F. } \\
\text { L.R. } \\
\text { T.D. } \\
\text { D.M. }\end{array}$ & $\begin{array}{l}34 \cdot 7 \pm I \cdot 5 \\
37 \cdot 0 \pm 1 \cdot 3 \\
39 \cdot 1 \pm 2 \cdot 7 \\
31 \cdot 4 \pm 2 \cdot 9 \\
30 \cdot 9 \pm 1 \cdot 0\end{array}$ & $\begin{array}{l}38 \cdot 8 \pm 3 \cdot 1 \\
37 \cdot 9 \pm 2 \cdot 5 \\
40 \cdot 7 \pm 3 \cdot 0 \\
32 \cdot 3 \pm 4 \cdot 2 \\
32 \cdot 2 \pm 2 \cdot 9\end{array}$ & $\begin{array}{l}33 \cdot 0 \\
36 \cdot 0 \\
36 \cdot 7 \\
36 \cdot 0 \\
36 \cdot 0\end{array}$ & $\begin{array}{l}46 \cdot 0 \\
46 \cdot 0 \\
88 \cdot 9 \uparrow \\
42 \cdot 4 \\
73 \cdot 7 \dagger\end{array}$ \\
\hline Female & $\begin{array}{l}\text { H.C. } \\
\text { E.L. } \\
\text { R.L. } \\
\text { M.D. } \\
\text { V.P. }\end{array}$ & $\begin{array}{l}25 \cdot 6 \pm 3 \cdot 5 \\
32 \cdot 5 \pm 2 \cdot 3 \\
36 \cdot 2 \pm 2 \cdot 7 \\
33 \cdot 1 \pm 1 \cdot 9 \\
44 \cdot 1 \pm 3 \cdot 9\end{array}$ & $\begin{array}{l}26 \cdot 0 \pm 3 \cdot 9 \\
32 \cdot 6 \pm 2 \cdot 3 \\
38 \cdot 2 \pm 1 \cdot 9 \\
34 \cdot 8 \pm 2 \cdot 0 \\
52 \cdot 0 \pm 6 \cdot 0\end{array}$ & $\begin{array}{l}3 \mathbf{I} \cdot 8 \\
3 \mathrm{I} \cdot 8 \\
33 \cdot 2 \\
3 \mathbf{I} \cdot 8 \\
32 \cdot 7\end{array}$ & $\begin{array}{l}27 \cdot 1 \\
47 \cdot 9 \\
45 \cdot 5 \\
38 \cdot 4 \\
65 \cdot 9\end{array}$ \\
\hline
\end{tabular}

* Mean values of daily measurements with their standard deviations.

+ Value unsatisfactory as the subject insisted on 'blowing-up' the Douglas bag and was hyperventilating.

\section{Calorie expenditure whilst sitting}

The individual calorie expenditures whilst sitting are shown in Table 3 . Excluding subjects L.R. and D.M. who could not be dissuaded from treating the Douglas bag as if it were a balloon, the calorie cost of sitting was on average $22 \%$ higher than the calorie cost of lying in bed. This value is much less than the $49 \%$ increase found by Garry, Passmore, Warnock \& Durnin (1955) in their energy expenditure measurements of twenty-nine Scottish miners and clerks.

\section{Physical efficiency}

Step-testing. The calorie cost of stepping was very constant for both the Lawrence Tavern and the control subjects, with little or no change during successive performances. The Lawrence Tavern subjects used fewer calories than the controls, the mean energy cost for the male test subjects being $4^{\mathrm{I}} \cdot 8 \mathrm{kcal}$ compared with $59^{\circ} \mathrm{I}$ kcal for the controls $(P<0.00 \mathrm{I})$; the mean energy cost for the female subjects was $34^{\circ} 4 \mathrm{kcal}$ compared with $4 \mathrm{I} \cdot 2 \mathrm{kcal}$ for the controls $(P<0.05)$. Individual values are shown in Table 4.

Since the control and test subjects were of unequal body size, the energy cost of 
stepping was compared with the predicted energy cost from Lundgren's formula (I948):

$$
Y=0.00244 X+0.460
$$

where $Y=$ oxygen consumption in $1 . / \mathrm{min}$, and $X=$ body-weight in $\mathrm{kg} \times$ step height in $\mathrm{m} \times$ no. of upsteps $/ \mathrm{min}$.

The energy cost of stepping fell below the predicted energy cost in all subjects (Table 4 ), but the test subjects were again significantly below the controls $(P<0.001$ for the males and $P<0.05$ for the females).

Table 4. Energy cost of the Io min step-test expressed in kcal and as a percentage of the predicted energy cost, together with the resting heart rate and the mean heart rate during 0.5 to $3.5 \mathrm{~min}$ of recovery

\begin{tabular}{|c|c|c|c|c|c|c|c|c|c|}
\hline \multirow[b]{2}{*}{ Subject } & \multicolumn{4}{|c|}{ Male } & \multicolumn{5}{|c|}{ Female } \\
\hline & $\begin{array}{l}\text { Calorie cost } \\
\text { of step-test* }\end{array}$ & $\begin{array}{l}\% \text { pre- } \\
\text { dicted } \\
\text { energy } \\
\text { cost }\end{array}$ & $\begin{array}{c}\text { Resting } \\
\text { heart } \\
\text { rate }\end{array}$ & $\begin{array}{l}\text { Re- } \\
\text { covery } \\
\text { heart } \\
\text { rate }\end{array}$ & Subject & $\begin{array}{l}\text { Calorie cost } \\
\text { of step-test* }\end{array}$ & $\begin{array}{l}\% \text { pre- } \\
\text { dicted } \\
\text { energy } \\
\text { cost }\end{array}$ & $\begin{array}{c}\text { Resting } \\
\text { heart } \\
\text { rate }\end{array}$ & $\begin{array}{c}\text { Re- } \\
\text { covery } \\
\text { heart } \\
\text { rate }\end{array}$ \\
\hline \multicolumn{10}{|c|}{ Test subjects } \\
\hline $\begin{array}{l}\text { J.B. } \\
\text { R.F. } \\
\text { L.R. } \\
\text { T.D. } \\
\text { D.M. }\end{array}$ & $\begin{array}{l}4 I \cdot 3 \pm 4 \cdot 0 \\
42 \cdot 6 \pm 5 \cdot 2 \\
40 \cdot 6 \pm 2 \cdot 3 \\
38 \cdot 1 \pm I \cdot 2 \\
46 \cdot 2 \pm 3 \cdot 3\end{array}$ & $\begin{array}{l}77 \\
80 \\
83 \\
73 \\
82\end{array}$ & $\begin{array}{l}48 \\
60 \\
70 \\
6 I \\
56\end{array}$ & $\begin{array}{l}58 \\
59 \\
71 \\
65 \\
69\end{array}$ & $\begin{array}{l}\text { H.C. } \\
\text { E.L. } \\
\text { R.L. } \\
\text { M.D. } \\
\text { V.P. }\end{array}$ & $\begin{array}{l}32 \cdot 9 \pm 1 \cdot 3 \\
33.9 \pm 1.3 \\
33 \cdot 1 \pm 0.9 \\
32.9 \pm 0.9 \\
390 \pm 1.8\end{array}$ & $\begin{array}{l}68 \\
71 \\
72 \\
72 \\
75\end{array}$ & $\begin{array}{l}79 \\
80 \\
88 \\
83 \\
83\end{array}$ & $\begin{array}{l}80 \\
90 \\
95 \\
90 \\
85\end{array}$ \\
\hline Mean & $41 \cdot 8$ & 79 & 59 & 64 & & $34 \cdot 4$ & 72 & 83 & 88 \\
\hline \multicolumn{10}{|c|}{ Control subjects } \\
\hline $\begin{array}{l}\text { F.B. } \\
\text { N.M. } \\
\text { D.W. } \\
\text { L.C. } \\
\text { C.C. }\end{array}$ & $\begin{array}{l}63 \cdot 7 \pm 3 \cdot 6 \\
60 \cdot 9 \pm 2 \cdot 0 \\
60 \cdot 6 \pm 2 \cdot 1 \\
57 \cdot 0 \pm 1 \cdot 6 \\
53 \cdot 1 \pm 2 \cdot 2\end{array}$ & $\begin{array}{l}95 \\
90 \\
95 \\
92 \\
96\end{array}$ & $\begin{array}{l}84 \\
75 \\
87 \\
70 \\
79\end{array}$ & $\begin{array}{l}92 \\
78 \\
90 \\
71 \\
87\end{array}$ & $\begin{array}{l}\text { G.B. } \\
\text { P.M. } \\
\text { J.I. } \\
\text { S.C. } \\
\text { J.G. }\end{array}$ & $\begin{array}{l}50 \cdot 4 \pm 2 \cdot 0 \\
42 \cdot 4 \pm 4 \cdot 4 \\
40 \cdot 0 \pm r \cdot 7 \\
38 \cdot 4 \pm 0 \cdot 9 \\
34 \cdot 9 \pm 1 \cdot 5\end{array}$ & $\begin{array}{l}84 \\
76 \\
80 \\
71 \\
80\end{array}$ & $\begin{array}{l}80 \\
70 \\
78 \\
84 \\
75\end{array}$ & $\begin{array}{r}82 \\
94 \\
98 \\
100 \\
95\end{array}$ \\
\hline Mean & $59^{\circ} \mathrm{I}$ & 94 & 79 & 84 & & $4 I \cdot 2$ & 78 & 77 & 94 \\
\hline
\end{tabular}

* Mean values of daily measurements with their standard deviations.

Resting heart rates were low in the male test subjects (Table 4 ), but not in the female ones. The mean heart rate during the $3 \mathrm{~min}$ of recovery after step-testing was only 5 beats/min higher than the resting value for both male and female test subjects and for the male controls. This very small difference could be due to the fact that the resting heart rates were based on measurements made immediately before step-testing, and anticipation of exercise may have increased the heart rate above the true resting value. However, the values were in good agreement with those obtained routinely by the nursing staff. The mean recovery heart rate for the female controls was 16 beats/ min higher than the resting rate, which suggests that they were the least physically fit group.

Brick carrying. The number of bricks carried at a time and the manner of carrying and stacking were usually very consistent for each subject. The energy expenditure measurements on the final day, however, were unpopular as most subjects felt very 
self-conscious wearing the Douglas bag apparatus. V.P. refused to co-operate, but six subjects were measured three times with varying loads and three subjects were measured twice.

In order to enable comparisons to be made, calorie expenditures were calculated for a $2 \mathrm{~h}$ period, which was the maximum time allotted for the moving of the bricks. In each instance, the calculated calorie expenditures were the sum of the calorie cost of moving all the bricks plus the calorie cost of sitting for whatever period of time remained out of the $2 \mathrm{~h}$.

Table 5. Energy cost (kcal/2 $h)$ of brick carrying: (a) usual style, (b) with more bricks/load and (c) with fever bricks/load*

$\begin{array}{ccccc}\text { Sex } & \text { Subject } & \text { Usual style } & \text { More bricks/load } & \text { Fewer bricks/load } \\ \text { Male } & \text { J.B. } & 254(6) & - & 269(5) \\ & \text { R.F. } & 226(6) & - & 276(5) \\ & \text { L.R. } & 278(5) & 262(6) & 299(3) \\ \text { T.D. } & 203(8) & - & 215(6) \\ \text { Female } & & 258(3) & 301(4) & - \\ & \text { D.M. } & 258(4) & 166(3) \\ & \text { H.C. } & 150(4) & 128(5) & 301(2) \\ & \text { E.L. } & 261(3) & 212(4) & 263(2) \\ & \text { R.L. } & 240(3) & 222(4) & 268(2) \\ & \text { M.D. } & 204(3) & 216(4) & \end{array}$

Table 5 shows the individual calorie expenditures $/ 2 \mathrm{~h}$ with varying loads. The first column relates to the calorie cost of moving the bricks in the manner chosen by each subject. The second column shows the calorie cost if more bricks at a time had been carried and the final column shows the calorie cost if fewer bricks had been in each load. The results showed that, in general, the subjects elected to carry a large number of bricks per load, and the calorie cost was increased whenever the subjects were made to carry smaller loads.

\section{DISCUSSION}

Individual differences in calorie intakes have been stated to be one of our major unsolved nutritional problems (Anonymous, 1966), and we are often confronted with the anomaly in which some individuals gain weight and become obese despite apparently eating very little, whilst others remain very thin even when they appear to have normal appetites. Many dietary surveys have recorded huge individual variations in calorie intakes which led Widdowson (1947) to suggest that the differences were due to some individuals being very much more efficient machines than others and therefore requiring less food.

The Jamaican dietary survey of Lawrence Tavern like many other nutritional surveys revealed some remarkably low intakes. The most obvious explanation is that, in spite of every care, the dietary surveys were not correct. The second possibility is the one suggested by Widdowson, that some people really live and work normally on such low intakes, and that by a process of adaptation they have become more efficient 
machines. A third possibility, well shown by the work of Keys, Brožek, Henschel, Mickelsen \& Taylor (1950), is that these subjects adapted to a low calorie intake by a reduction in their voluntary energy expenditure. The present results suggest that all three factors may be involved.

It was not possible to do such detailed studies on more than a small number of subjects, and therefore it is necessary to some extent to discuss the findings individually. It is obvious that precise conclusions about the accuracy of the dietary surveys cannot be drawn from I week's observation in the metabolic ward, because the levels of physical activity in the ward and at home were not necessarily the same. Although in the course of the field study as detailed records as possible were kept of occupation and activity, it is impossible to compute from these the $24 \mathrm{~h}$ calorie expenditure. I can only record the impression that on the whole the subjects were probably rather less active in the ward than at home. Even at home many of them spent a large part of the day in sedentary occupations, e.g. plaiting straw and playing dominoes.

The male subjects were slightly underweight compared with the local standard, and four of the five female subjects were 10-24\% lighter than the average for the district (Table I). Moreover, in the Lawrence Tavern population as a whole the heights, weights and weight:height ratios are very much below those in the USA (Ashcroft et al. 1966).

Judged by the criteria of weight change and $\mathrm{N}$ balance, it seems that in four subjects -L.R., T.D., E.L. and M.D.- - the surveys could have given a correct picture of the dietary intakes. By the same criteria in three other subjects-J.B., R.F. and V.P.the surveys must have underestimated the intakes. It was possible that J.B., who was very impoverished, was enduring extra deprivations in the hope of receiving some aid; V.P. was suspected of supplementing her diet at the village shop. In the remaining three subjects-D.M., H.C. and R.L.-the changes in weight and in $\mathrm{N}$ balance were of doubtful significance. However, from calculations of the $24 \mathrm{~h}$ energy expenditures it appeared likely that the calorie intakes of D.M. and R.L. had been underestimated, since their $24 \mathrm{~h}$ expenditures exceeded their intakes. Subject H.C. appeared to be in calorie balance, suggesting that her intakes could have been correct.

Three subjects require special mention. M.D. was very greatly underweight-I $4 \mathrm{~kg}$ less than the Lawrence Tavern standard — and had the lowest calorie intake: yet on this intake she was able to maintain her weight in the ward and had a small positive $\mathrm{N}$ balance. She was lethargic and the least active of the subjects. During the week's survey she did nothing that could compare with the brick carrying as regards calorie cost; it is even possible that she was more active in the ward than at home. Estimates of her $24 \mathrm{~h}$ calorie expenditure showed that she had in fact very few surplus calories available for physical activity. Subject H.C. had a similar low calorie intake but was less underweight than M.D. On the other hand, she had the lowest BMR and the lowest energy expenditure when sitting, step-testing and brick carrying. Subject V.P. had a relatively high calorie intake, and yet lost weight and was in negative $\mathrm{N}$ balance. This girl had a consistently high resting metabolic rate; she was afebrile and not underweight. She was given a radioactive iodine uptake test in which I $8 \%$ of the dose was detected over the neck at $6 \mathrm{~h}$ and $34 \%$ was detected at $24 \mathrm{~h}$. In Jamaica the upper 
limits of normal at 6 and $24 \mathrm{~h}$ are $\mathrm{I} 8$ and $35 \%$. Personal history and clinical examination revealed nothing to suggest thyrotoxicosis but the possibility remains of undetected infection.

Keys et al. (1950), in their studies of the victims of famine and of experimental subjects on a semi-starvation diet, obtained evidence of an adaptation to the low calorie intakes in the form of a decrease in BMR. The results in Table 3 show that the metabolic rate during the night was in all but one subject (V.P.) fairly close to the expected BMR, if the latter is corrected, by deducting $10 \%$, for the mean difference between Jamaica and the reference environmental temperature. It is possible that this correction recommended by FAO is an overestimate. If this correction is ignored, the mean difference between the minimal metabolic rate in our subjects (excluding V.P.) and the standard BMR was $4.4 \mathrm{kcal} / \mathrm{m}^{2}$ per $\mathrm{h}$, that is, a mean reduction of $12 \%$. This is small compared with the reduction of $3 \mathrm{I} \%$ found by Keys et al. (1950) in experimental semi-starvation. It may be that there is a difference here between subjects who are relatively acutely undernourished and have lost a substantial proportion of their body-weight, and people who have been on a low plane of nutrition all their lives, and rather than losing weight have simply failed to achieve the levels reached by those who are better fed.

Passmore \& Durnin (1955), in a review of the pattern of metabolism during sleep, report a number of studies which have found decreases in metabolism during sleep of about $7-10 \%$ below basal levels. They emphasize, however, that the majority of these studies have been short-period experiments and they suggest that the mean rate of energy expenditure throughout a normal night's sleep is very close to the BMR. In the present study eight subjects had minimal metabolic rates which were less than $5 \%$ below their basal levels, and the overall energy expenditure during the entire night was $3 \%$ above the basal level.

In the Minnesota experiment on semi-starvation (Keys et al. 1950), the subjects were receiving a mean intake of $1570 \mathrm{kcal} /$ day, leaving a surplus of $488 \mathrm{kcal}$ for physical work; they showed a very marked reduction in activity. In the present study, in the subjects in whom the surveys were thought to be correct or nearly correct, the calories available for physical work were of the same order. The work diaries confirmed that several of the subjects, e.g. D.M., H.C. and M.D., exerted themselves very little. However, none of the subjects showed the signs of weakness or depression which were found in the Minnesota experiment.

Physical efficiency in the Minnesota experiment was found to be unchanged after semi-starvation. The Lawrence Tavern subjects, however, performed a standard step-test with a much lower calorie expenditure than well-fed control subjects, and this was unrelated to their differences in body-weight.

It was also of interest that, in the experiment with carrying bricks, on the whole the subjects of their own choice carried out the task in a way that was economical of energy.

The relatively small increase in the energy expenditure of Lawrence Tavern subjects when sitting compared with that when lying in bed was interesting since, for those subjects about whom information was reliable, the extent of the increase was related to their calorie intake $(P<0.05)$. Subject H.C., whose calorie intake was $6 \mathrm{I} \%$ of the 
FAO requirement, had an increase in energy expenditure when sitting of only $4 \%$. Subject E.L., whose calorie intake came nearest to the FAO requirement, had an increase in energy expenditure of $47 \%$, which was very similar to the $49 \%$ increase found by Garry et al. (1955) in normal subjects. Subjects M.D. and T.D. with intermediate calorie intakes had increases in energy expenditure of 10 and $31 \%$ respectively.

In the Minnesota experiment heart rates fell rapidly during semi-starvation, and during both world wars bradycardia was mentioned as an outstanding finding in practically every case of famine oedema or starvation. However, it was unlikely that malnutrition was responsible for the low resting heart rates found in the Lawrence Tavern study since low rates were confined to the male subjects.

Although the number of subjects was small, the following general conclusions can perhaps be drawn from this study:

(1) Some of the very low calorie intakes recorded from apparently normal people in dietary surveys must be considered open to suspicion.

(2) However, it is possible that in Jamaica many people live and work on calorie intakes which represent only about $60-70 \%$ of the FAO requirement.

(3) These people are underweight for their height, and their level of activity is low.

(4) We have obtained no clear-cut evidence of an adaptive change in BMR. On the other hand, what work is done appears to be carried out with a high degree of efficiency.

Grateful acknowledgement is due to Dr J. S. Garrow who suggested this study and to Professor J. C. Waterlow for help and guidance. I am especially grateful to $\mathrm{Dr}$ R. H. Fox and his colleague Mr H.S. Wolff of the MRC Human Physiology Unit, Holly Hill, London, who were responsible for designing and providing most of the equipment, and $I$ wish to thank them for their most helpful advice and interest throughout the study.

I wish to thank Nurse Clarke for selecting the Lawrence Tavern subjects and getting their co-operation and Mr Duncan who selected the Penfield subjects. Mr Evans of the Jamaica Government Food Technology Division kindly freeze-dried sixty-eight meals for which I am most grateful. Finally, I especially wish to thank the volunteers from Lawrence Tavern and Penfield, and Francis Blackman, Lloyd Cole, Neville McMillan, Douglas Welds, Gloria Brown, Stephanie Campbell, Judith Garel, Janet Isaacs and Pauline Muschett who acted as the control subjects.

\section{A P PENDIX}

\section{Further details of the home environment of the subjects}

f.B. (Lawrence Tavern), male, aged 32 years, cultivator; lives with wife and eight children (aged 16 months-12 years) in a very small two-roomed house made of wattle and daubed with mud. Extremely poor and virtually no furniture or cooking utensils. House perched on hilltop about to min walk from road. Water is obtained from river at foot of hill. Grows cassava and a few bananas, coconut, breadfruit and mangoes on 
a small plot surrounding the house. Also grows some yam and maize on another plot a fair distance away. Income of a few shillings a week from straw-work. Keeps no domestic animals except four hens which do not lay. Illiterate; children rarely go to school. Does not show much initiative; apathetic and reluctant to co-operate. Lethargic.

R.F. (Lawrence Tavern), male, aged 18 years, nephew of J.B.; lives with mother, father and six brothers and sisters (aged 4-18 years) in modest two-roomed house of wood and concrete. Furniture includes two beds, table, china cabinet, radio and clock. House is 25 min walk from road and shop. Water is carried from river at foot of steep hill. Helps father grow a multitude of different crops in 3 acres surrounding houseten different tree crops and fourteen different vegetables. Vegetables are sold in Kingston market and he has additional income from straw-work. Keeps eighteen hens (but only one laying), one piglet and one goat kid. Literate. Very enthusiastic, energetic young man and most co-operative.

L.R. (Penfield), male, aged I7 years; was garage-hand but now unemployed. Lives with mother, father and about six of his twelve brothers and sisters. House is small, two-roomed and made of wattle and daub with a cement covering, situated 5 min walk from main road up steep hill. Little furniture other than beds. Father is a mason and although he has some land it is not cultivated. Some money comes from relatives in England. Water is carried from a standpipe on the main road. Spends most of the day in village with friends talking or playing dominoes. Literate, co-operative and lively.

$T . D$. (Penfield), male, aged 18 years; lives with grandmother, cousin and friend in a very small dilapidated wattle and daub house. New cement block house under construction. Modest furniture and cooking utensils. House is $7 \mathrm{~min}$ walk from road and 3o min from shop. Water is obtained from standpipe on road. Unemployed. Grandmother takes in washing. No cultivation. Spends most of day in village $I_{2} \frac{1}{2}$ miles from home with L.R. playing dominoes. Literate and very helpful energetic young man.

$D . M$. (Penfield), male, aged 18 years; lives with mother and five younger brothers and sisters in small wattle and daub house with cement rendering. House is Io min walk from village and shop. Furniture sparse and few cooking utensils. Water is carried from the river nearby. Land adjoining house is not cultivated. Unemployed but does occasional labouring. Mother works as a domestic help or does casual labour. Spends most of day in village playing dominoes. Literate, co-operative, fairly lethargic.

H.C. (Lawrence Tavern), female, aged 20 years; lives with mother, father and five younger brothers and sisters. House is of wood with two small rooms. Furniture includes beds, china cabinet, table, chairs and radio. House is to min walk from road and shop. Water is carried from river at foot of very steep hill. Father owns 10.5 acres of land and grows various starchy roots and tubers, coconut, bananas, pineapple and vegetables. Additional income from straw-work. Keeps one cow, six laying hens, one sow and piglet, six rabbits and guinea-pigs. H.C. helps around the house, carries water, goes to the shop and spends much of the time doing straw-work. Literate, bright girl from pleasant, intelligent family.

E.L. and R.L. (Lawrence Tavern), females, aged 20 and $\mathrm{I} 6$ years respectively; live with mother, father and twelve other younger brothers and sisters. House is very small, two-roomed and made of wattle and daub. New cement block house under con- 
struction at rear. Very little furniture or cooking utensils. House is about roo yd from road and water and 5 min walk from shop. Father owns 5 acres of land and grows starchy roots, bananas, cocoa, cane and a few fruit trees and keeps two piglets. E.L. and R.L. help with the housework and do straw-work for sale. Literate, co-operative girls, fairly sluggish.

$M . D$. (Lawrence Tavern), female, aged 21 years; has lived with uncle, aunt, and two other adult relatives and three children for 4 months. Previously was at home with parents and nine brothers and sisters. Uncle's house is of wood and has three rooms with modest furniture. House is $40 \mathrm{yd}$ from road and water and 2 min walk from shop. Uncle owns 5 acres but has hypertension and rarely cultivates them. Various tree crops and some starchy roots and tubers. Keeps two pigs and ten laying hens. M.D. helps with the cooking and straw-work but does no housework. Literate, helpful, inactive.

V.P. (Lawrence Tavern), female, aged I7 years; lives with nine brothers and sisters (aged I year-23 years) in a shabby one-roomed wattle and daub house. Furniture consists of two beds, table, two chairs and radio. Parents in England and eldest brother looks after the 4 acres of steep hillside cultivation bearing yam, sweet potato and banana. House is on top of steep hill about $5 \mathrm{~min}$ from road and standpipe, and ro min from shop. V.P. carries water, washes clothes and looks after the house. She does straw-work for a considerable portion of the day. Illiterate, unintelligent, energetic.

\section{REFERENCES}

Anonymous ( 1966). Nutr. Rev. 24, 39.

Ashcroft, M. T., Ling, J., Lovell, H. G. \& Miall, W. E. (1966). Br. F. prev. soc. Med. $20,22$.

Atwater, W. O. (Igoz). Rep. Storrs agric. Exp. Stn, rgor.

Atwater, W. O. \& Bryant, A. P. (1900). Rep. Storrs agric. Exp. Stn, 1899.

Du Bois, D. \& Du Bois, E. F. (1916). Archs intern. Med. 17, 863 .

Durnin, J. V. G. A. (196r). Proc. Nutr. Soc. 20, 52.

Edholm, O. G. (r96r). Proc. Nutr. Soc. 20, 7 r.

FAO: Second Committee on Calorie Requirements (1957). F.A.O. nutr. stud. no. I5.

Fleisch, A. (195I). Helv. med. acta 18, 23.

Furnass, S. B. (1959). F. Physiol, Lond. 149, 63 P.

Garry, R. C., Passmore, R., Warnock, G. M. \& Durnin, J. V. G. A. (1955). Spec. Rep. Ser. med. Res. Coun. no. 289 .

Keys, A., Brožek, J., Henschel, A., Mickelsen. O. \& Taylor, H. L. (1950). The Biology of Human Starvation. Vol. I. Minneapolis: The University of Minnesota Press.

Lundgren, N. P. V. (1948). Proc. Congr. int. Mal. prof. Ix. London, p. 273.

Passmore, R. \& Durnin, J. V. G. A. (1955). Physiol. Rev. 35, 801.

Widdowson, E. M. (1947). Spec. Rep. Ser. med. Res. Coun. no. 257.

Wolff, H. S. (1958). Q. Fl exp. Physiol. 43, 270. 